\author{
Z.B. Sabirov ${ }^{1,2}$, A.B. Eshmagambetova ${ }^{2}$, G.K. Turlybekova ${ }^{2}$, \\ N.M. Duzbayeva ${ }^{2}$, M.A. Mukasheva ${ }^{2}$, I.A. Onoshko ${ }^{3}$ \\ ${ }^{I}$ Institute of Public Health and Professional Health of Medical University of Karaganda, Karaganda, Kazakhstan; \\ ${ }^{2}$ Karagandy University of the name of academician E. A. Buketov, Karaganda, Kazakhstan; \\ ${ }^{3}$ Municipal state institution «Middle School of General education № 63», Karaganda, Kazakhstan \\ *Corresponding author: audacious_zap@mail.ru
}

\title{
Biochemical parameters of blood plasma of the male population living on the territory of the Aral Sea
}

\begin{abstract}
The Aral Sea ecological disaster zone affects the health status of the population living in this zone. Biochemical parameters are indicators of the metabolic functionality of the body. The article presents data about the biochemical parameters of blood plasma in the male population living in the ecological crisis zone of the Aral Sea region. It is shown that when determining the majority of indicators of biochemical analysis within the physiological norm, there is a significant percentage of people with deviations in these indicators. Such data make it possible to assume about the factors that can affect the entire population and have massive manifestations. Certainly, these factors, include the negative impact of the environment on public health. An increase in gamma - glutamyltransferase was found in $41 \%$ of the subjects, an increase in cholesterol in $38 \%$ and an increase in triglycerides in $34 \%$. In the inhabitants of the Aral Sea, a correlation was found between the biochemical parameters of blood serum from the dose of chemicals. It was shown that long-term chemical load in the crisis zone of the Aral Sea region causes a deviation of protein metabolism. The results obtained indicate a significant percentage of people with metabolic stress in the process of adaptation to high chemical load.
\end{abstract}

Keywords: a biochemical analysis, frequency of manifestation of a trait, metabolic parameters, gammaglutamyltransferase, environmental pollution, ecology.

\section{Introduction}

As a result of partial shallowing and drying of the Aral Sea, a technogenic biogeochemical province arose in the Aral Sea region of Kazakhstan [1]. One of the risk factors in the Aral Sea region is persistent chemical pollutants (POPs), which have the ability to influence metabolic processes in the human body, creating conditions for the development of various pathologies [2]. According to the comprehensive sanitary and hygienic assessment (2014 - 2016), the hazard index of environmental pollution in the city of Aralsk is at the level of 48 points, in accordance with this criterion, the territory belongs to the crisis zone [3].

Endotoxins can cause metabolic changes, which in turn is a pathogenetic link in the development of metabolic syndrome, multiple organ failure, and ischemic damage [4-5]. There is no doubt that the greatest effect in the prevention of organ disorders can be achieved at the initial stages, when prenosological mechanisms has a leading role in the pathogenesis of the disease process [6].

It is known that the detoxification of chemical xenobiotics mainly occurs in the liver. Changes in the activity of enzymes in the biological fluid ( $\gamma$-glutamyl transferase, alanine aminotransferase, aspartate aminotransferase) indicates a dysfunction of the hepatobiliary system. A decrease in the amount or function of hepatic metabolic enzymes (gamma-glutamyl transpeptidase, albumin, alanine aminotransferase, aspartate aminotransferase), indicates an increase in hydrolysis and a violation of biosynthetic processes in the liver. Due to the fact that these enzymes normally bind and remove all toxins during the transport and metabolic function, their reduction (hypoenzinomy) negatively affects the functional state of the body. As a result, there is an accumulation of non-neutralized xenobiotics and various metabolic products and, as a result, endotoxicosis develops. According to the literature data, indicators of biochemical blood test informatively show the severity of metabolic disorders and the degree of adaptation to stressful situations [5, 7-9].

Currently, metabolic disorders are considered as one of the risk factors in the development of many disorders and pathologies. This determines the relevance of the study of metabolic changes in the body in conditions of ecological trouble.

The aim of the work was to determine the state of the metabolic status of men living in the ecological crisis zone of the Aral Sea region. 


\section{Methodology}

Biochemical blood tests were carried out for 13 parameters of blood plasma - alanine aminotransferase (ALAT), aspartate aminotransferase (ASAT), total amylase, total protein, glucose, gamma-glutamyl transferase (GGT), creatinine, urea, alkaline phosphatase (ALP), cholesterol, triglyceride acid (MC), uric acid, medium molecules. A total of 209 men living in the city of Aralsk were examined. Biochemical studies were performed on a StarDust MC-15 semi-automatic analyzer (Germany, 2010) using reagents from «DyaSys».

To perform a biochemical blood test in men living in the city of Aralsk, a group was formed, which included persons meeting the following criteria: a) age from 18 to 69 years; b) male persons; c) living in the area for at least 10 years; d) having no contact with harmful working conditions.

The research materials were processed by mathematical and statistical methods using Statistica 10.0 software for statistical data processing. Statistical processing of the data included calculating the median, arithmetic means $(\mathrm{M})$, standard errors of arithmetic means $(\mathrm{m})$, confidence intervals $(\mathrm{CI})$, and standard deviation for variables with normal distribution. Normality of distribution was checked by evaluating the Shapiro-Wilk test and the Kolmogorov-Smirnov test. To identify a linear relationship, Pearson's pair correlation coefficient was used for indicators with a normal distribution.

\section{Results and Discussion}

Biochemical studies of blood plasma of the male population aged 18-69 years living in the city of Aralsk are presented in Table 1 (quantitative analysis). A quantitative analysis showed that the average values of biochemical parameters in blood plasma of the male population living in the city of Aralsk were within the physiological norm, the exception was the average value of total protein, which exceeded the established norm by 3 units and amounted to $88 \mathrm{~g} / \mathrm{l}$. But it is worth noting that several indicators showed an excess of physiological norms at the upper limit of the confidence interval: asat - up to $39 \mathrm{U} / \mathrm{L}$, total protein — up to $92 \mathrm{~g} / \mathrm{L}, \mathrm{GGT}$ - up to $43 \mathrm{U} / \mathrm{L}$ and triglycerides — up to $1.9 \mathrm{mmol} / \mathrm{l}$.

T a b l e 1

Biochemical parameters of blood plasma of the male population living in the city of Aralsk (quantitative analysis)

\begin{tabular}{|c|c|c|c|c|}
\hline $\begin{array}{c}\text { Blood biochemical } \\
\text { parameters }(\mathrm{N}=209)\end{array}$ & Physiological norms & $\mathrm{M}$ & $\mathrm{CI}$ & $\begin{array}{l}\text { Standard } \\
\text { deviation }\end{array}$ \\
\hline ALAT & Up to 40 units/1 & 27 & $20 \pm 35$ & 1.2 \\
\hline ASAT & Up to 37 units/1 & 30 & $24 \pm 39$ & 1.2 \\
\hline Amylase & Up to 110 units/1 & 63 & $49 \pm 81$ & 1.7 \\
\hline Total Protein & $65-85 \mathrm{~g} / 1$ & 88 & $83 \pm 92$ & 0.6 \\
\hline Glucose & $4.2-6.2 \mathrm{mmol} / \mathrm{L}$ & 4.4 & $4.1 \pm 4.8$ & 0.09 \\
\hline GGT & $7-32$ units/1 & 29 & $24 \pm 43$ & 1.4 \\
\hline Creatinine & $62-115 \mathrm{mmol} / \mathrm{l}$ & 75 & $65 \pm 84$ & 1.1 \\
\hline Urea & $1.7-8.3 \mathrm{mmol} / \mathrm{l}$ & 3.4 & $2.5 \pm 4.4$ & 0.1 \\
\hline ALP & Up to 117 units/1 & 89 & $75 \pm 101$ & 1.6 \\
\hline Cholesterol & Up to $5.12 \mathrm{mmol} / \mathrm{L}$ & 4.8 & $4.3 \pm 5.8$ & 0.2 \\
\hline Triglycerides & $0.14-1.82 \mathrm{mmol} / \mathrm{L}$ & 1.3 & $1 \pm 1.9$ & 0.1 \\
\hline Uric acid & $202-416 \mathrm{mmol} / \mathrm{L}$ & 315 & $247 \pm 347$ & 13.4 \\
\hline Medium molecules & $0.2-0.3$ units $/ 1$ & 0.3 & $0.2 \pm 0.9$ & 0.1 \\
\hline
\end{tabular}

Although the mean values were within the physiological norm, it is important to emphasize that this revealed a significant percentage of the subjects with deviations in several biochemical parameters. Frequency biochemical analysis of the blood of the adult male population living in the city of Aralsk aged 18-69 years has revealed that:

1) an increase in the ALAT content was observed in $16 \%$ of the examined individuals;

2) an increase in ASAT in $27 \%$;

3) an increase in total protein in $61 \%$;

4) an increase in GGT in $41 \%$, an increase in cholesterol in $38 \%$;

5) an increase in triglycerides in $34 \%$;

6) an increase in medium molecules in $23 \%$. 
There was also a decrease in the content of such biochemical parameters as glucose ( $28 \%$ of the subjects), creatinine (14\% of the subjects), medium molecules ( $29 \%$ of the subjects).

Thus, it can be noted that the biochemical parameters for which changes were most often found in frequency analysis are total protein, GGT, cholesterol and triglycerides (Table 2).

Table 2

\section{Biochemical parameters of blood plasma of the male population living in the city of Aralsk (frequency analysis)}

\begin{tabular}{|c|c|c|c|c|}
\hline $\begin{array}{l}\text { Blood biochemical } \\
\text { parameters }(N=209)\end{array}$ & Physiological norms & $\begin{array}{l}\text { Percentage of examined, \% } \\
\qquad \mathrm{M} \pm \mathrm{m}\end{array}$ & $\mathrm{CI}$ & $\begin{array}{l}\text { Standard } \\
\text { deviation }\end{array}$ \\
\hline ALAT & Up to 40 units/1 & & & \\
\hline within normal limits & & $84 \pm 2.5$ & $84.6 \pm 83.9$ & 6.4 \\
\hline above normal limits & & $16 \pm 2.5$ & $16.1 \pm 15.4$ & 6.4 \\
\hline ASAT & Up to 37 units/1 & & & \\
\hline within normal limits & & $73 \pm 3.1$ & $78.8 \pm 66.6$ & 9.5 \\
\hline above normal limits & & $27 \pm 3.1$ & $33.4 \pm 21.1$ & 9.5 \\
\hline Amylase & Up to 110 units/1 & & & \\
\hline within normal limits & & $94 \pm 1.6$ & $94.5 \pm 94.0$ & 2.6 \\
\hline above normal limits & & $6 \pm 1.6$ & $5.9 \pm 5.6$ & 2.6 \\
\hline Total Protein & $65-85 \mathrm{~g} / 1$ & & & \\
\hline within normal limits & & $39 \pm 3.4$ & $45.5 \pm 32.0$ & 11.4 \\
\hline above normal limits & & $61 \pm 3.4$ & $67.9 \pm 54.5$ & 11.4 \\
\hline Glucose & $4.2-6.2 \mathrm{mmol} / \mathrm{L}$ & & & \\
\hline within normal limits & & $68 \pm 3.2$ & $74.9 \pm 61.9$ & 10.0 \\
\hline below normal limits & & $28 \pm 3.1$ & $33.9 \pm 21.5$ & 10.0 \\
\hline above normal limits & & $4 \pm 1.3$ & $4.0 \pm 3.7$ & 1.8 \\
\hline GGT & $7-32$ units/1 & & & \\
\hline within normal limits & & $59 \pm 3.4$ & $65.7 \pm 52$ & 11.6 \\
\hline above normal limits & & $41 \pm 3.4$ & $47.9 \pm 34.3$ & 11.6 \\
\hline Creatinine & $62-115 \mathrm{mmol} / \mathrm{l}$ & & & \\
\hline within normal limits & & $85 \pm 2.5$ & $85 \pm 84$ & 6.2 \\
\hline below normal limits & & $14 \pm 2.4$ & $14.7 \pm 14.0$ & 5.9 \\
\hline above normal limits & & $1 \pm 0.7$ & $1.1 \pm 0.9$ & 0.5 \\
\hline Urea & $1.7-8.3 \mathrm{mmol} / \mathrm{l}$ & & & \\
\hline within normal limits & & $95 \pm 1.5$ & $94.9 \pm 94.5$ & 2.4 \\
\hline below normal limits & & $5 \pm 1.5$ & $4.9 \pm 4.6$ & 2.2 \\
\hline above normal limits & & $0.5 \pm 0.5$ & $0.6 \pm 0.4$ & 0.2 \\
\hline $\mathbf{A L P}$ & Up to 117 units/l & & & \\
\hline within normal limits & & $86 \pm 2.4$ & $86.5 \pm 85.8$ & 5.7 \\
\hline above normal limits & & $14 \pm 2.4$ & $14.2 \pm 13.5$ & 5.7 \\
\hline Cholesterol & $\mathrm{Up}$ to $5.12 \mathrm{mmol} / \mathrm{L}$ & & & \\
\hline within normal limits & & $62 \pm 3.4$ & $68.4 \pm 54.9$ & 11.3 \\
\hline above normal limits & & $38 \pm 3.4$ & $45.0 \pm 31.6$ & 11.3 \\
\hline Triglycerides & $0.14-1.82 \mathrm{mmol} / \mathrm{L}$ & & & \\
\hline within normal limits & & $64 \pm 3.3$ & $70.7 \pm 57.5$ & 11.0 \\
\hline below normal limits & & $2 \pm 0.9$ & $2.1 \pm 1.8$ & 0.9 \\
\hline above normal limits & & $34 \pm 3.3$ & $40.5 \pm 27.4$ & 10.7 \\
\hline Uric acid & $202-416 \mathrm{mmol} / \mathrm{L}$ & & & \\
\hline within normal limits & & $83 \pm 2.7$ & $83.2 \pm 82.4$ & 7.1 \\
\hline below normal limits & & $11 \pm 2.2$ & $10.9 \pm 10.3$ & 4.8 \\
\hline above normal limits & & $7 \pm 1.8$ & $6.8 \pm 6.3$ & 3.1 \\
\hline Medium molecules & $0.2-0.3$ units $/ 1$ & & & \\
\hline within normal limits & & $48 \pm 2.7$ & $53.3 \pm 42.7$ & 7.1 \\
\hline below normal limits & & $29 \pm 2.4$ & $34.1 \pm 24.4$ & 5.9 \\
\hline above normal limits & & $23 \pm 2.2$ & $27.2 \pm 18.3$ & 5.0 \\
\hline
\end{tabular}


In $41 \%$ of men, an increase in gamma-glutamyltransferase is observed, which indicates long-term exposure to chemical factors of «low intensity» and, as a reaction of the body, autosensitization processes are possible. A relationship was found between the GGT index and the dose load of sulfates received by inhalation $(r=0.3, p<0.05)$. Based on the revealed correlation, a predictive model was built $y=19.59+0.14 x$, regression coefficient $R=0.3$, determination coefficient $R 2=0.052$, Fisher coefficient $F=15.45$, model estimate $p<0.005$.

A relationship was found between the urea indicator in people living in the crisis zone and the dose load of sulfur dioxide, which is inhaled $(r=0.31, p<0.05)$. Based on the revealed correlation, a prognostic model was built at $y=2.41+0.02 x$, regression coefficient $R=0.311$, determination coefficient $R 2=0.096$, Fisher coefficient $F=60.29$, model estimate $p<0.005$.

As you know, GGT is a marker reflecting the work of the liver and hepatobiliary tract, including damage to cell membranes under the influence of toxic agents [10], and urea reflects the work of the kidneys and the degree of impairment of the filtration and excretory functions of the organ. Due to the fact that the processes of biotransformation of alien substances occur in the liver, gastrointestinal tract, lungs, kidneys, this can confirm the metabolic mechanisms of the formation of diseases caused by environmental exposure, and indicate the detected correlations [11].

\section{Conclusions}

Massive changes in the parameters of biochemical analysis indicate that the reason is extensive, and can affect the spread of traits in whole population. These reasons include the environmental impact of environmental factors on the health of the population, which is also confirmed by correlation analysis and literature data. Apparently, the change in some metabolic parameters in a certain part of the population occurs due to different variations in resistance to environmental environmental factors that affect the body. Because the exposure for each participant of study was the same, the body's reserves aimed at maintaining homeostasis are the key to functioning, neutralization and metabolic stability under conditions of living in unfavorable environmental conditions.

The results obtained indicate a significant tension of the metabolic status in the examined individuals in the process of adaptation to a high chemical load. According to the obtained data, the organs - targets in conditions of ecological trouble are the liver and kidneys, which is consistent with the literature data. Longterm chemical load in the crisis zone of the Aral Sea region in the exposed population, in particular, in persons of reproductive age, causes a violation of protein metabolism. The results obtained indicate a significant percentage of people with metabolic stress in the process of adaptation to high chemical load.

\section{References}

1 Закон Республики Казахстан от 30 июня 1992 г. № 1468-XII «О социальной защите граждан, пострадавших вследствие последствий экологического бедствия в Приаралье». - [Электронный pecypc]. - URL: http://adilet.zan.kz/rus/docs/Z920002600.

2 Титов В.Н. Становление в филогенезе биологической функции эндоэкологии. Поддержание «чистоты» межклеточной среды в паракринных сообществах клеток, органах и в организме (лекция) / В.Н. Титов // Клиническая лабораторная диагностика. - 2014. - Т. 59, № 10. - С. 27-37.

3 Zhang W. Distribution characteristics and assessment of heavy metals in the surface water of the Syr Darya River, Kazakhstan / W. Zhang, L. Ma, J. Abuduwaili, Y. Ge, G. Issanova, G. Saparov // Polish Journal of Environmental Studies. — 2019. — Vol. 29, No. 1. - P. 979-988.

4 Сидельникова В.И. Эндогенная интоксикация и воспаление: последовательность реакций и информативность маркеров / В.И. Сидельникова, А.Е. Черницкий, И.И. Рецкий // Сельскохозяйственная биология. — 2015. — № 2. — С. $152-161$.

5 Титов В.Н. Мочевая кислота. Биология, биохимия и диагностическое значение в роли интегрального теста / В.Н. Титов, В.А. Дмитриев, Е.В. Ощепкова // Клиническая лабораторная диагностика. — 2009. - № 1. - С. $23-35$.

6 Рязанцева Н.В. Невротические расстройства: клинико-биохимические параллели / Н.В. Рязанцева, В.В. Новицкий // Клиническая лабораторная диагностика. — 2003. — № 5. - С. 5-8.

7 Namazbaeva Z. Change in metabolic and cognitive state among people of the Aral zone of ecological disaster / Z. Namazbaeva, S. Battakova, L. Ibrayeva, Z. Sabirov // Israel Journal of Ecology and Evolution. — 2018. — Vol. 64. - P. 44-55.

8 Namazbaeva Z.I. The Assessment of Halogenating Stress in Population by the Environmental and Health Monitoring / Z.I. Namazbaeva, G.N. Dosybaeva, Z.B. Sabirov, L.T. Bazelyuk, G.K. Asanov, I.O. Baidaulet // International Journal of Environmental and Science Education. - 2016. - Vol. 11, No. 10. - P. 3884-3893.

9 Srivastava A.K. Clinical biochemical and neurobehavioural studies of workers engaged in the manufacture of quinalphos. / A.K. Srivastava, B.N. Gupta, V. Bihari, N. Mathur, L.P. Srivastava, B.S. Pangtey et al. // Food Chem. Toxicol. — 2000. — Vol. 38. - P. 65-69. 
10 Келина Н.Ю. Методика оценивания состояния пациентов с кардиологической патологией на основе иммунобиохимического анализа крови с учетом экологического фона региона / Н.Ю. Келина, В.В. Пикулин, Т.Ю. Мамелина, О.А. Куликова // Технология живых систем. — 2012. — № 7. — С. 65-69.

11 Дзугкоев С.Г. Системный окислительный стресс и биохимические маркеры повреждения внутренних органов / С.Г. Дзугкоев, И.В. Можаева, Л.В. Гиголаева, А.И. Тедтоева, Е.А. Такоева, Ф.С. Дзугкоева и др. // Фундаментальные исследования. - 2014. - № 3 (7). - С. 478-481.

\author{
Ж.Б. Сабиров, А.Б. Ешмагамбетова, Г.К. Турлыбекова, \\ Н.М. Дузбаева, М.А. Мукашева, И.А. Оношко

\section{Арал маңындағы ер адам тұрғындарының қан плазмасының биохимиялық көрсеткіштері}

- Арал маңындағы экологиялық апат аймағы сол жерде тұрып жатқан тұрғындардың денсаулық жағдайына әсер етеді. Биохимиялық көрсеткіштер ағзаның функционалды метаболиттік индикаторлары болып табылады. Мақалада Арал маңындағы экологиялық апат аймағында тұрып жатқан ер адам тұрғындарының биохимиялық қан плазмасының көрсеткіштері берілген. Физиологиялық нормада көптеген биохимиялық көрсеткіштердің талдауын анықтау барысында, берілген көрсеткіштер бойынша бірталай ауытқушылық бар екендігі байқалды. Мұндай мәліметтер арқылы барлық популяцияға және жаппай таралуға әсер ету факторы болуы мүмкін. Осындай факторларға қоршаған ортаның экологиялық келеңсіз әсерін жатқызуға болады. Тексеруден өткендерден гаммаглутамилтрансферазалардың ұлғаюы $41 \%$, холестериннің ұлғаюы $38 \%$ және триглицеридтердің ұлғаюы 34 \% анықталды. Сонымен қатар, Арал өңірінің тұрғындарында химиялық заттардың дозасынан қан сарысуының биохимиялық көрсеткіштері арасындағы себеп-салдарлық байланыс анықталды. Арал өңірінің дағдарыс аймағындағы ұзақ химиялық жүктеме ақуыз алмасуының бұзылуына әкелетіні көрсетілген. Арал маңының қауіпті аймағындағы ұзақ химиялық жүктеме ақуызды алмасудың бұзылуын туғызатындығы дәлелденген. Берілген нәтижелерде жоғары химиялық жүктемеге бейімделу процесінде метаболиттік күйзеліске ұшыраған адамдар саны едәуір жоғары екені байқалып отыр.

Кілт сөздер: биохимиялық талдау, белгінің пайда болу жиілілігі, метаболиттік көрсеткіштер, гаммаглутамилтрансфераза, қоршаған ортаның ластануы, экология.

\title{
Ж.Б. Сабиров, А.Б. Ешмагамбетова, Г.К. Турлыбекова, Н.М. Дузбаева, М.А. Мукашева, И.А. Оношко
Биохимические показатели плазмы крови мужского населения Приаралья

\begin{abstract}
Зона экологического бедствия Приаралья оказывает влияние на состояние здоровья проживающего там населения. Биохимические показатели являются индикаторами метаболической функциональности организма. В статье представлены данные о биохимических показателях плазмы крови у мужского населения, проживающего в зоне экологического неблагополучия Приаралья. Показано, что при определении большинства показателей биохимического анализа в пределах физиологической нормы, наблюдается значительный процент лиц с отклонениями по данным показателям. Такие данные позволяют судить о факторах, способных оказывать влияние на всю популяцию и иметь массовые проявления. К таким факторам, безусловно, можно отнести негативное экологическое воздействие окружающей среды. Авторами выявлено увеличение гамма-глутамилтрансферазы у 41 \% обследуемых, увеличение холестерина - у 38 \% и увеличение триглицеридов - у 34 \%. Кроме того, установлена причинно-следственная связь у жителей Приаралья между биохимическими показателями сыворотки крови от дозы химических веществ. Показано, что длительная химическая нагрузка в кризисной зоне Приаралья вызывает нарушение белкового обмена. Полученные результаты свидетельствуют о значительном проценте лиц, имеющих метаболический стресс, в процессе адаптации к высокой химической нагрузке.
\end{abstract}

Ключевые слова: биохимический анализ, частота встречаемости признака, метаболические показатели, гамма-глутамилтрансфераза, загрязнение окружающей среды, экология. 


\section{References}

1 Zakon Respubliki Kazakhstan ot 30 iiunia 1992 hoda No. 1468-XII «O sotsialnoi zashchite hrazhdan, postradavshikh vsledstvie posledstvii ekolohicheskoho bedstviia v Priarale» [Law of the Republic of Kazakhstan of June 30, 1992 «On social protection of citizens affected by the consequences of an environmental disaster in the Aral Sea region»]. adilet.zan.kz. Retrieved from http://adilet.zan.kz/rus/docs/Z920002600/ [in Russian].

2 Titov, V.N. (2014). Stanovlenie v filoheneze biolohicheskoi funktsii endoekolohii. Podderzhanie «chistoty» mezhkletochnoi sredy v parakrinnykh soobshchestvakh kletok, orhanakh i v orhanizme (lektsiia) [Formation in the phylogeny of the biological function of endoecology. Maintaining the «purity» of the intercellular environment in communities paracrine cells and organs in the body (lecture)]. Klinicheskaia laboratornaia diahnostika - Clinical Laboratory Diagnostics, 59, 10, 27-37 [in Russian].

3 Zhang, W., Ma, L., Abuduwaili, J., Ge, Y., Issanova, G. \& Saparov, G. (2019). Distribution characteristics and assessment of heavy metals in the surface water of the Syr Darya River, Kazakhstan. Polish Journal of Environmental Studies, 29, 1, 979-988.

4 Sidelnikova, V.I., Chernitsky, A.E. \& Retsky, M.I. (2015). Endohennaia intoksikatsiia i vospalenie: posledovatelnost reaktsii i informativnost markerov [Endogenous intoxication and inflammation: the sequence of reactions and the information content of markers]. Selskokhoziaistvennaia biolohiia - Agricultural Siology, 2, 152-161 [in Russian].

5 Titov, V.N., Dmitriev, V.A., \& Oschepkova, E.V. (2009). Mochevaia kislota. Biolohiia, biokhimiia i diahnosticheskoe znachenie $\mathrm{v}$ roli intehralnoho testa [Uric acid. Biology, biochemistry and diagnostic value as an integral test]. Klinicheskaia laboratornaia diahnostika - Clinical Laboratory Diagnostics, 1, 23-35 [in Russian].

6 Ryazantseva N.V., \& Novitsky, V.V. (2003). Nevroticheskie rasstroistva: kliniko-biokhimicheskie paralleli [Neurotic disorders: clinical-and-biochem1cal parallels]. Klinicheskaia laboratornaia diahnostika - Clinical Laboratory Diagnostics, 5, 5-8 [in Russian].

7 Namazbaeva, Z., Battakova, S., Ibrayeva, L., \& Sabirov, Z. (2018). Change in metabolic and cognitive state among people of the Aral zone of ecological disaster. Israel Journal of Ecology and Evolution, 64, 44-55.

8 Namazbaeva, Z.I., Dosybaeva, G.N., Sabirov, Z.B., Bazelyuk, L.T., Asanov, G.K., \& Baidaulet, I.O. (2016). The Assessment of Halogenating Stress in Population by the Environmental and Health Monitoring. International Journal of Environmental and Science Education, 11, 10, 3884-3893.

9 Srivastava, A.K., Gupta, B.N., Bihari, V., Mathur, N., Srivastava, L.P., \& Pangtey, B.S. et al. (2000). Clinical, biochemical and neurobehavioural studies of workers engaged in the manufacture of quinalphos. Food and chemical toxicology, 38, 65-69.

10 Kelina, N.J., Pikulin, V.V., Mamelina, T.J., \& Kulikova, O.A. (2012). Metodika otsenivaniia sostoianiia patsientov s kardiolohicheskoi patolohiei na osnove immuno-biokhimicheskoho analiza krovi s uchetom ekolohicheskoho fona rehiona [Technique of estimation of the condition of patients with cardiological pathology on the basis of immuno - the biochemical analysis of blood taking into account the ecological background of the region]. Tekhnolohiia zhivykh sistem - Technologies of Living Systems, 7, 65-69 [in Russian].

11 Dzugkoev, S.G., Mozhaeva, I.V., Gigolaeva, L.V., Takoeva, E.A., Dzugkoeva, F.S., \& Margieva, O.I. et al. (2014). Sistemnyi okislitelnyi stress i biokhimicheskie markery povrezhdeniia vnutrennikh orhanov [System oxidative stress and biochemical markers of the damage of internal organs]. Fundamentalnye issledovaniia - Basic research, 3(7), 478-481 [in Russian]. 